\title{
SUSCEPTIBILITY OF DIABETIC HEART TO CATECHOLAMINE-INDUCED ARRHYTHMIAS IS INDEPENDENT OF CONTRACTILE DYSFUNCTION
}

Adriana Adameova ${ }^{1, \#}$, Vijayan Elimban ${ }^{1}$, Delfin Rodriguez-Leyva ${ }^{3}$, Paramiit S. Tappia ${ }^{2}$ and Naranjan S Dhalla

${ }^{1}$ Institute of Cardiovascular Sciences, St. Boniface Hospital Research Centre and Department of Physiology, Faculty of Medicine, University of Manitoba

${ }^{2}$ Asper Clinical Research Institute, Winnipeg, Canada ${ }^{3}$ V.I. Lenin University Hospital, Cuba

\section{OSETLJIVOST SRCA NA IATEHOLAMINIMA IZAZVANE ARITMIJE JE NEZAVISNA OD KONTRAKTILNE DISFUNKCIJE U DIJABETESU

Received / Primljen: 12.03.2014.

Accepted / Prihvaćen: 20.05.2014.

\section{ABSTRACT}

Background: Diabetes is associated with myocardial electrical instability and prolongation of action potential duration that result in disturbances in the rhythm of the heart.

Objective: This study was undertaken to examine the role of circulating catecholamines in abnormal cardiac rhythm and contractility during different stages of diabetes.

Methods: Diabetes was induced in male Sprague-Dawley rats with streptozotocin (STZ; $65 \mathrm{mg} / \mathrm{kg}$, i.v.). Epinephrine (4-128 $\mu \mathrm{g} / \mathrm{kg}$, i.v.) -induced arrhythmias and plasma levels of epinephrine (Epi) and norepinephrine (NE) were determined in control, 4- and 8-wk diabetic animals. Echocardiography was used to assess cardiac remodeling and contractile function.

Results: Although diabetes induced cardiac dysfunction, there were no significant differences in cardiac output, ejection fraction, left ventricle ( $L V)$ dimensions, $L V$ fractional shortening between the 4- and 8-wk diabetic animals. The electrocardiogram of both diabetic groups showed deep $S$ wave as well as changes in T wave and ST segment. In addition, prolongation of the RR interval in the 4-and 8-wk diabetic animals was seen, while prolongation of the QT and $P R$ intervals were only seen in the 8-wk diabetic animals. The severity of Epi-induced ventricular arrhythmias, as assessed by arrhythmia score, was significantly lower in the 8-wk diabetic rats, as compared to the 4-wk diabetic animals. Circulating Epi levels were significantly decreased in the 8-wk diabetic rats, whereas NE levels were increased in the 4-wk diabetic rats.

Conclusions: The sensitivity of the diabetic heart to catecholamine-triggered arrhythmias may be dependent on circulating Epi rather than NE and thus it can be proposed that the increased incidence of sudden cardiac death in diabetics may not be associated with response to catecholamines.

Key words: diabetes, arrhythmias, cardiac dysfunction, norepinephrine, epinephrine

\section{SAŽETAK}

Uvod: Dijabetes je udružen sa električnom nestabilnošću miokarda i produženim trajanjem akcionog potencijala što rezultuje poremećajima srčanog ritma.

Cilj: Ova studija je sprovedena sa ciljem da ispita ulogu cirkulišućih kateholamina kod poremećaja srčanog ritma $i$ kontraktilnosti miokarda tokom različitih stadijuma dijabetesa.

Metode: Kod muških pacova soja Sprague - Dawley dijabetes je izazvan streptozocinom (STZ; $65 \mathrm{mg} / \mathrm{kg}$, i.v.). Aritmije izazvane adrenalinom $(4-128 \mu \mathrm{g} / \mathrm{kg}$, i.v.) $i$ koncentracija adrenalina $i$ noradrenalina detektovane su u kontrolnoj grupi $i$ nakon 4. $i$ 8. nedelje kod životinja kojima je indukovan dijabetes. Remodelovanje srca kao i kontraktilna funkcija su procenjene ehokardiografijom.

Rezultati: Iako je dijabetes izazvao poremećaj srčane funkcije, nije bilo značajnijih razlika u udarnom volumenu, ejekcionoj frakciji, dimenzijama leve komore, frakcionom skraćenju leve komore između životinja koje imaju dijabetes 4 i 8 nedelja. Elektrokardiogram obe grupe životinja sa dijabetesom pokazao je duboki S talas i promene u T talasu i ST segmentu. Pored toga, došlo je do produženja RR intervala kod životinja koje imaju dijabetes 4 i 8 nedelja, dok se produženje QT i PR intervala javilo samo kod životinja koje imaju dijabetes 8 nedelja. Opasnost od ventikularnih aritmija izazvanih adrenalinom, koja se procenjuje pomoću aritmija skora, bila je značajno niža kod životinja koje imaju dijabetes 8 nedelja u poredenju sa životinjama koje imaju dijabetes 4 nedelje. Nivoi cirkulišućeg adrenalina su bili značajno niži kod životinja koje imaju dijabetes 8 nedelja, dok su nivoi noradrenalina bili povišeni kod životinja koje imaju dijabetes 4 nedelje.

Zaključak: Osetljivost dijabetičnog srca na aritmije izazvane kateholaminima može zavisiti više od koncentracije cirkulišuceg adrenalina nego od koncentracije noradrenalina, zbog čega se može pretpostaviti da povećana incidenca iznenadnih srčanih smrti u dijabetesu ne mora biti povezana sa odgovorom na kateholamine.

Ključne reči: dijabetes, aritmije, poremećaji srčane funkcije, noradrenalin, adrenalin 


\section{ABBREVIATIONS}

4DM, 4-week diabetes

8DM, 8-week diabetes

AS, arrhythmia score

CaMKII, Ca2+/calmodulin-dependent protein kinase II

cAMP, cyclic AMP

$\mathrm{CO}$, cardiac output

CON, control group

ECG, electrocardiogram

$\mathbf{E F}$, ejection fraction

Epi, epinephrine

FS, fractional shortening

HPLC, high performance liquid chromatography

$\mathbf{L V}$, left ventricle
LVEDV, LV end-diastolic volume

LVESV, LV end-systolic volume

LVFS, LV fractional shortening

LVIDD, left ventricular internal diameter diastole

LVIDS, left ventricular internal diameter systole.

NE, norepinephrine

PKA, protein kinase A

PVBs, premature ventricular beats

PWTd, diastolic posterior wall thickness

PWTs, systolic posterior wall thickness

SR, sarcoplasmic reticulum

STZ, streptozotocin

VT, ventricular tachycardia

\section{INTRODUCTION}

The overactivation of the sympathetic nervous system is invariably seen in subjects with high risk for sudden cardiac death and elevated circulating catecholamine levels are considered to result in lethal ventricular arrhythmias and subsequent sudden cardiac death (1-4). Such arrhythomogenic effects of catecholamines are generally believed to occur, in part, by producing defects in intracellular $\mathrm{Ca}^{2+}$-handling (1-4). In addition, oxyradicals, which are known to generate oxidative stress, may play a critical role in the genesis of ventricular arrhythmias that may result in sudden cardiac death (1-4). Both bradycardia and malignant ventricular arrhythmias occur in diabetic subjects $(5,6)$. Prolongation of the action potential duration leading to myocardial electrical instability predisposes the heart to rhythm disturbances and is considered to be a main feature of cardiac dysfunction of diabetic subjects (7-10). In addition, the diabetic heart is characterized by an early asymptomatic left ventricular diastolic dysfunction followed by late systolic dysfunction $(11,12)$.

Although diabetic cardiomyopathy is a frequent complication of diabetes, the mechanisms are not completely understood. In view of the fact that the activation of the sympathetic nervous system is associated with the occurrence of arrhythmias as well as impaired cardiac function, the present study was undertaken to investigate if the susceptibility to catecholamine-induced arrhythmias is correlated to the stage or duration of diabetes by employing a well-established streptozotocin (STZ) rat model that clinically resembles human type 1 diabetes. Furthermore, we examined if the extent of the cardiac dysfunction is correlated to the duration of the diabetic state. This is the first study to report that the susceptibility to catecholamine-induced ventricular arrhythmias may be dependent on the stage of diabetes and that long-term diabetes may be associated with increased resistance to catecholamine-induced ventricular arrhythmias.

\section{MATERIALS AND METHODS}

\section{Animals}

All experimental protocols for animal studies were approved by the Animal Care Committee of the University of Manitoba, following the Guidelines established by the Canadian Council on Animal Care. Male Sprague-Dawley rats (200-220 g each) were kept at 12-h day/night cycle and fed rat chow and water ad libitum. After one week of quarantine, the rats were randomly assigned into 3 groups; control (CON), a 4-wk diabetes (4DM) and 8-wk diabetes (8DM).

\section{Induction of experimental}

streptozotocin-induced diabetes

Diabetes was induced in rats by a single tail-vein injection $(65 \mathrm{mg} / \mathrm{kg}$ ) of streptozotocin (STZ) dissolved in $0.1 \mathrm{M}$ citrate buffer, pH 4.5, as described previously (13). CON animals were injected with the vehicle only. The blood glucose levels were tested by using the Sigma kit for glucose determination (Sigma) and plasma insulin was measured using a standard radioimmunoassay technique as described elsewhere (13).

\section{ECG parameters}

Six-lead electrocardiographic (ECG) monitoring (leads I-III, augmented vector right aVR, augmented vector left $\mathrm{aVL}$ and augmented vector foot $\mathrm{aVF}$ ) was used and different ECG parameters such as PQ, QRS, RR, and QT intervals were obtained from baseline recordings (AcqKnowladge 3.0.3 software). Measurement of all variables was performed in a blinded manner. No attempt was made to correct QT for heart rate because previous studies have shown that QT interval was not rate-dependent in rats (14).

\section{Epinephrine-induced arrhythmias}

Epinephrine (Epi) treatment was performed as previously described $(4,15)$. Briefly, the tail vein of anesthetized rats was cannulated and cumulative doses of Epi given intravenously in a bolus of $4,8,16,32,64,128 \mu \mathrm{g} / \mathrm{kg}$ at 


\begin{tabular}{|l|l|l|l|}
\hline \multicolumn{4}{|l|}{ 4DM } \\
\hline A. General characteristics & C DM \\
\hline Body weight (g) & $555 \pm 26$ & $347 \pm 11^{*}$ & $358 \pm 17^{*}$ \\
\hline Plasma glucose (mM) & $7.9 \pm 0.4$ & $37.3 \pm 2.5^{*}$ & $34.6 \pm 0.8^{*}$ \\
\hline Plasma insulin (pM) & $57.8 \pm 9.7$ & $35.3 \pm 3.5^{*}$ & $16.8 \pm 1.2^{*} \#$ \\
\hline B. Electrocardiographic parameters (msec) \\
\hline PR & $0.035 \pm 0.001$ & $0.033 \pm 0.002$ & $0.39 \pm 0.001^{*}$ \\
\hline QRS & $0.060 \pm 0.002$ & $0.058 \pm 0.001$ & $0.057 \pm 0.002$ \\
\hline QT & $0.093 \pm 0.004$ & $0.094 \pm 0.002$ & $0.100 \pm 0.002^{*}$ \\
\hline RR & $0.175 \pm 0.007$ & $0.193 \pm 0.007^{*}$ & $0.211 \pm 0.006^{*}$ \\
\hline
\end{tabular}

Table 1. General characteristics and electrocardiographic parameters of the controlas well as 4- and 8-wk diabetic rats.

10 min intervals or until death of the animals. A 10-min baseline and continues ECG until the last Epi injection was recorded. Epi-induced arrhythmias including premature ventricular beats (PVBs), bigemines, salvos and ventricular tachycardias, were analyzed according to the Lambeth Conventions (16). Ventricular tachycardia (VT) was defined as a run of three or more consecutive ectopic beats. In addition, each individual animal was evaluated by means of a 6-point arrhythmia score (AS), and an assigned number corresponded to the most severe type of arrhythmia observed in that animal. AS was used for the group analysis of the severity of arrhythmias.

\section{Echocardiography}

An ultrasound imaging system (SONOS 5500 ultrasonograph (Agilent Technologies, Mississauga, ON, Canada) was used for the measurement of cardiac output, heart rate, left ventricular (LV) wall size and internal diameters during systole and diastole as well as fractional shortening (FS) and ejection fraction (EF). Echocardiographic measurements were conducted in rats anesthetized using $2.5 \%$ isoflurane in $2 \mathrm{l} / \mathrm{min}$ of oxygen. Briefly, the transthoracic short-axis measurements were performed using a $12-\mathrm{MHz}$ annular array ultrasound transducer. The M- mode images of posterior wall of the LV at the level of the papillary muscle were obtained for posterior wall thickness (PWT) and chamber dimensions. Images were stored in digital format on a magnetic optical disk for analysis. LV systolic function was assessed by calculating LV fractional shortening (LVFS) using the formula (LV end-diastolic diameter - LV end-systolic diameter) x 100/LV end-diastolic diameter. Cardiac output (CO), LV end-diastolic volume (LVEDV) and LV end-systolic volume (LVESV) were calculated using the following formulas:

$\mathrm{CO}=$ (heart rate $\mathrm{x}$ stroke volume $) / 1000, \mathrm{LVEDV}=7$ (LV end-diastolic diameter $)^{3} /(2.4+\mathrm{LV}$ end-diastolic diameter) and LVESV $=7$ (LV end-systolic diameter $)^{3} /(2.4+\mathrm{LV}$ end-systolic diameter). All these parameters were determined from at least 3 consecutive cardiac cycles (17).

\section{Measurement of plasma catecholamines}

Plasma from blood collected from the abdominal aorta of experimental animals was used to assess both norepi-

\begin{tabular}{|c|c|c|c|}
\hline $\begin{array}{l}\text { Heart rate (beats/min) } \\
\text { Stroke volume }(\mathrm{ml})\end{array}$ & $\begin{array}{c}361 \pm 5 \\
0.90 \pm 0.02\end{array}$ & $\begin{array}{r}301 \pm 17^{*} \\
0.62 \pm 0.07^{*}\end{array}$ & $\begin{array}{c}296 \pm 13^{*} \\
0.71 \pm 0.04^{*}\end{array}$ \\
\hline Cardiac output (ml/min) & $247 \pm 5$ & $184 \pm 15^{*}$ & $210 \pm 14^{*}$ \\
\hline Fractional shortening (\%) & $54 \pm 1$ & $40 \pm 3^{*}$ & $45 \pm 2^{*}$ \\
\hline Ejection fraction (\%) & $84 \pm 3$ & $76 \pm 3^{*}$ & $81 \pm 1^{*}$ \\
\hline $\begin{array}{l}\text { LV volume }(\mathbf{m l}) \\
\text { Systolic }\end{array}$ & $0.11 \pm 0.02$ & $0.22 \pm 0.04^{*}$ & $0.18 \pm 0.01^{*}$ \\
\hline Diastolic & $0.71 \pm 0.02$ & $0.91 \pm 0.07^{*}$ & $0.90 \pm 0.03^{*}$ \\
\hline $\begin{array}{l}\text { LVID }(\mathbf{m m}) \\
\text { Systolic }\end{array}$ & $3.47 \pm 0.19$ & $4.35 \pm 0.35^{*}$ & $4.15 \pm 0.03^{*}$ \\
\hline Diastolic & $6.79 \pm 0.08$ & $7.39 \pm 0.21^{*}$ & $7.40 \pm 0.10^{*}$ \\
\hline $\begin{array}{l}\text { PWT (mm) } \\
\text { Systolic }\end{array}$ & $2.85 \pm 0.17$ & $2.26 \pm 0.17^{*}$ & $2.19 \pm 0.15^{*}$ \\
\hline Diastolic & $2.05 \pm 0.18$ & $1.53 \pm 0.14^{*}$ & $1.55 \pm 0.11^{*}$ \\
\hline
\end{tabular}

Table 2. Echocardiographic parameters of the control, 4- and 8-week diabetic rats.

nephrine (NE) and Epi levels by the Bio-Rad plasma Ca reagent kit and high performance liquid chromatography (HPLC) with electrochemical detection as previously described (4).

\section{Statistical analysis}

Data are expressed as means \pm S.E.M. for 5-8 animals per group. One-way analysis of variance (ANOVA) followed by Duncan`s multiple test were used for comparison of differences in parametric variables among the groups. Statistical differences between two mean values were evaluated by Student's t-test. The incidence of arrhythmias was expressed as percentage and compared by using the $2 \times 2$ Chi-square test. Since the episodes of arrhythmias are not normally distributed, these data were compared using Mann-Whitney test. $\mathrm{P}<0.05$ indicated a significant difference.

\section{RESULTS}

General characteristics and cardiac function of the 4-wk and 8-wk diabetic animals

The diabetic state of the animals was confirmed by the elevated blood glucose and marked reduction in insulin levels following STZ injection (Table 1) as reported in our previous studies $(13,18-20)$. Although a further decline in the insulin levels was seen in the 8-wk diabetic animals, this did not result in a further increase in blood glucose levels. Diabetes was also associated with lower body weights, with no differences between the 4-wk and 8-wk diabetic animals (Table 1). ECG revealed a prolongation of the RR intervals in both 4- and 8-wk diabetic rats without any changes in QRS complex whereas a prolongation of the PR and QT intervals was seen in the 8-wk diabetic rats only (Table 1).

Representative echocardiographic images depicting the changes in left ventricular internal diameter (LVID) are shown in Figure 1 and the analysis of the data for different parameters of cardiac performance is given in Table 2. Although the heart rate, stroke volume, CO, EF 


\begin{tabular}{|c|c|c|c|c|c|c|}
\hline \multicolumn{2}{|c|}{ Dose of Epi } & \multicolumn{2}{|c|}{ Incidence PVBs } & \multicolumn{3}{|c|}{ Number of episodes PVBs } \\
\hline$(\mu \mathbf{g} / \mathbf{k g})$ & $\mathrm{CON}$ & 4DM & 8DM & CON & 4DM & 8DM \\
\hline 4 & $1 / 8(13 \%)$ & $1 / 5(20 \%)$ & $0 / 5(0 \%)$ & $0.88 \pm 0.88$ & $4.20 \pm 4.2$ & $0.00 \pm 0.00$ \\
\hline 8 & 3/8 (38\%) & $4 / 5(80 \%)$ & $1 / 5(20 \%)$ & $0.75 \pm 0.41$ & $2.80 \pm 1.83$ & $0.20 \pm 0.20^{\#}$ \\
\hline 16 & $4 / 8(50 \%)$ & $4 / 5(80 \%)$ & $3 / 5(60 \%)$ & $8.38 \pm 7.53$ & $7.40 \pm 5.22$ & $2.00 \pm 0.89 \%$ \\
\hline 32 & 7/8 (88\%) & $5 / 5(100 \%)$ & $5 / 5(100 \%)$ & $3.75 \pm 1.49$ & $10.83 \pm 4.13 *$ & $3.40 \pm 0.75^{\#}$ \\
\hline 64 & $8 / 8(100 \%)$ & $5 / 5(100 \%)$ & $5 / 5(100 \%)$ & $8.25 \pm 2.39$ & $8.75 \pm 3.40$ & $3.60 \pm 1.69^{* \#}$ \\
\hline 128 & $8 / 8(100 \%)$ & $5 / 5(100 \%)$ & $4 / 5(80 \%)$ & $12.00 \pm 2.88$ & $10.40 \pm 2.25$ & $4.40 \pm 1.63^{\prime \prime \#}$ \\
\hline
\end{tabular}

The values are mean \pm SEM of 5-8 experiments. The percentage of animals showing the incidence of PVBs are in brackets at each dose of Epr. CON, control; 4DM, 4-wk diabetes; 8DM, 8-wk diabetes. Significant at "P $<0.05$ vs. CON; ${ }^{\#}<0.05$ vs. $4 \mathrm{DM}$

and FS were depressed in the 4-wk diabetic animals, further depressions in these parameters were not seen in the 8-wk diabetic animals (Table 2). Both LV volume and LVID in systole and diastole were increased in the 4-wk diabetic rats, but no further increases were seen in the 8 -wk diabetic rats (Table 2). On the other hand, PWT in both systole and diastole were decreased in the 4-wk diabetic rats; however, no further changes were seen in the 8-wk diabetic animals.

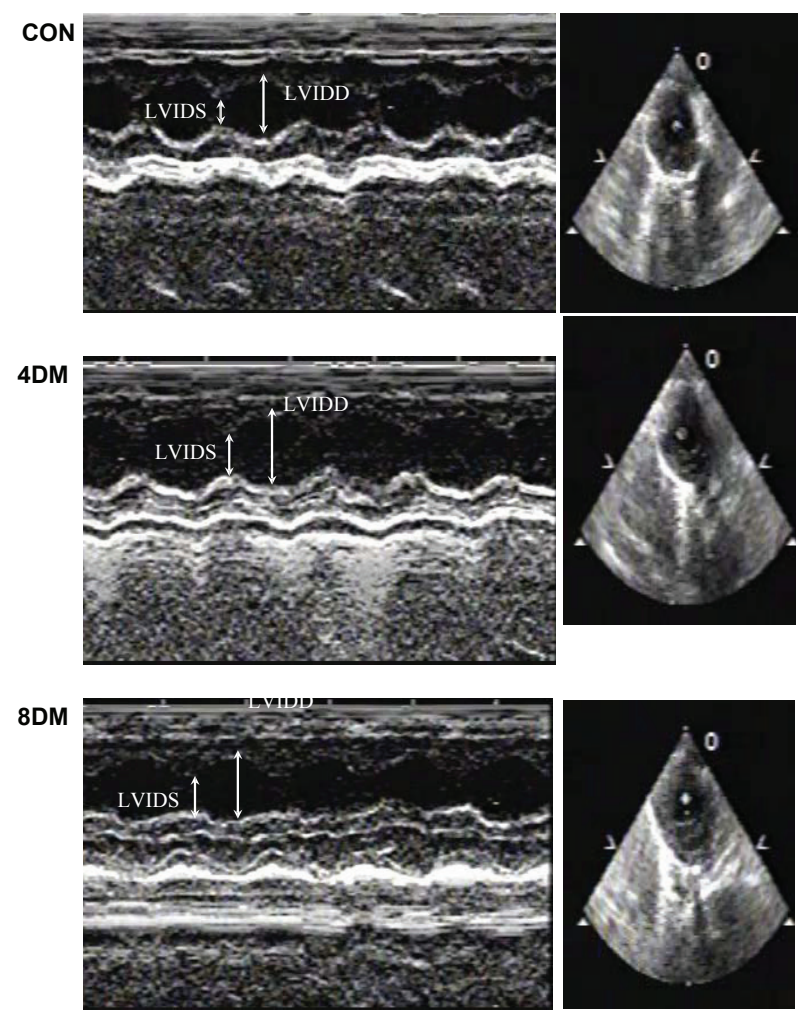

Figure 1. Baseline transthoracic echocardiographic images. 2D (left panel) and M-mode (right panel) images are shown for control (CON), 4-wk diabetes (4DM) and 8-wk diabetes (8DM). LVIDD, left ventricular internal diameter diastole; LVIDS, left ventricular internal diameter systole.

\section{ECG Parameters}

Abnormalities in the $\mathrm{T}$ wave, ST segment and deep S wave were observed in both the 4- and 8- wk diabetic groups (Figure 2A). No ventricular arrhythmias were observed in either of the diabetic groups during stabilization. Figures $2 \mathrm{~B}$ and $2 \mathrm{C}$ show representative ECG recordings following Epi injections. It can be seen that Epi triggered various types of ventricular arrhythmias and the most frequently developed arrhythmias observed were PVBs (Figure 2C).

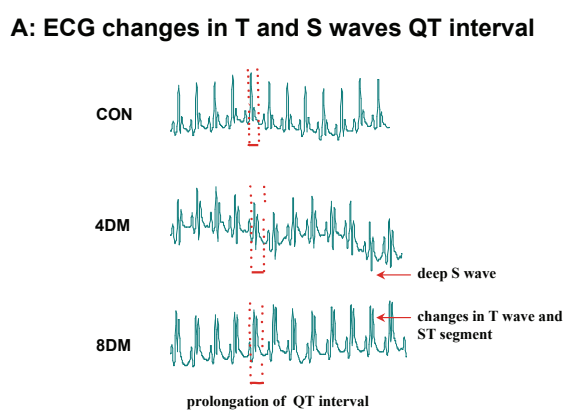

B: Normal ECG

C: ECG showing different types of arrhythmias
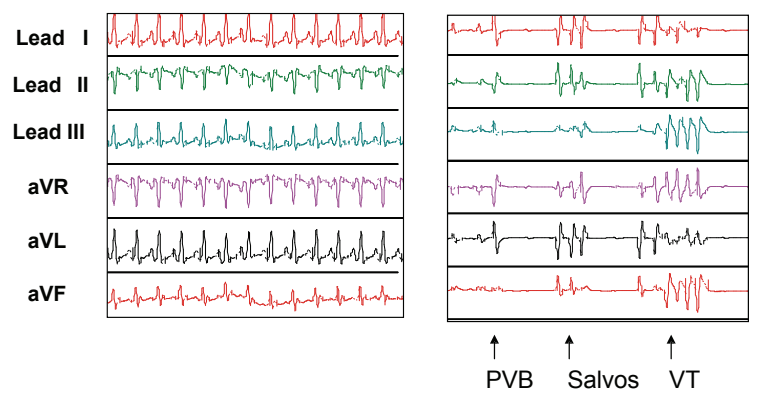

Figure 2. A. Baseline ECG recordings of lead III of the control, 4- and 8 -wk diabetic animals with the indications of the $\mathrm{T}$ wave abnormalities, QT prolongation and deep S wave. B. Representative 6- lead ECG recording of a control animal before and $\mathrm{C}$. following epinephrine administration. CON, control; 4DM, 4-wk diabetes; 8DM, 8-wk diabetes; PVBs, premature ventricular beats; VT, ventricular tachycardia. 


\begin{tabular}{|l|l|l|l|l|l|l|}
\hline Dose of Epi & \multicolumn{3}{|c|}{ Number of episodes of all VA } & \multicolumn{4}{c|}{ Duration of VA } \\
\hline$(\mu \mathbf{g} / \mathbf{k g})$ & CON & 4DM & 8DM & CON & 4DM & 8DM \\
\hline 4 & $0.88 \pm 0.88$ & $4.40 \pm 4.40$ & $0.00 \pm 0.00$ & $0.11 \pm 0.11$ & $0.63 \pm 0.73$ & $0.00 \pm 0.00$ \\
\hline 8 & & & & & & \\
\\
\hline
\end{tabular}

The values are mean \pm SEM of 5-8 experiments. CON, control; 4DM, 4-wk diabetes; 8DM, 8-wk diabetes. Significant at * P<0.05 vs. CON; $\mathrm{P}<0.05$ vs. $4 \mathrm{DM}$

Table 4. Influence of 4- and 8-wk diabetes on the number of episode and duration of all ventricular arrhythmias (VA) induced by cumulative doses of epinephrine (Epi).

Ventricular arrhythmias induced by cumulative doses of epinephrine in 4- and 8-wk diabetic animals

At low doses $(4-16 \mu \mathrm{g} / \mathrm{kg})$ of Epi, the incidence of PVBs was lower in the 8-wk diabetes group as compared to the 4-wk diabetes group. On the other hand, lower number of episodes of PVBs were observed with high doses (32-128 $\mu \mathrm{g} / \mathrm{kg}$ ) of Epi in the 8-wk diabetic animals as compared to the 4-wk diabetic rats (Table 3). A lower sensitivity to Epiinduced ventricular arrhythmias as well as shorter duration times of arrhythmias were also observed in the 8-wk diabetic animals, as compared to the 4-wk diabetic animals (Table 4).

\section{Arrhythmia score and plasma catecholamine \\ levels in 4- and 8-wk diabetic rats}

The overall severity of ventricular arrhythmias, expressed as AS, was significantly lower in the 8-wk diabetic animals, as compared to both 4-wk diabetic and control animals, whereas that in the 4-wk diabetic rats was similar to control values (Figure 3A). In order to determine if sympathetic nervous activity was increased in the 4- and 8-wk diabetic animals, catecholamine levels in the plasma were measured. Although Epi levels did not differ between the control and 4-wk diabetic rats, Epi levels were significantly lower in the 8-wk diabetic animals (Figure 3B). However, in contrast, NE levels were markedly higher in the 4-wk diabetes group whereas no change was seen in the 8-wk diabetic animals, as compared to control values (Figure $3 \mathrm{C}$ ).

\section{DISCUSSION}

The present study was undertaken to investigate the association of the sensitivity of the diabetic heart to Epi and incidence of ventricular arrhythmias as well as cardiac remodeling and dysfunction in rats at different stages of diabetes. Although comparable cardiac remodeling and impaired cardiac function was seen in both the 4-wk and 8-wk diabetic animals, a prolongation of the RR interval was seen in the 4-wk diabetic animals, which was further increased in the 8- wk diabetic animals. This suggests that the depression in the conduction of the electrical impulse may be dependent on the stage of diabetes. In addition,

A: Arrhythmia scores
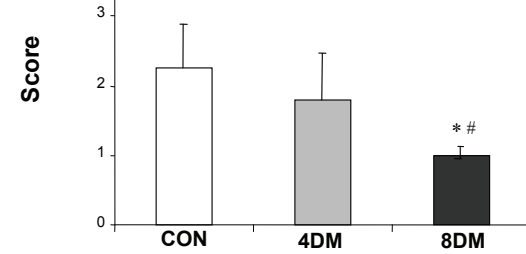

B: Plasma epinephrine
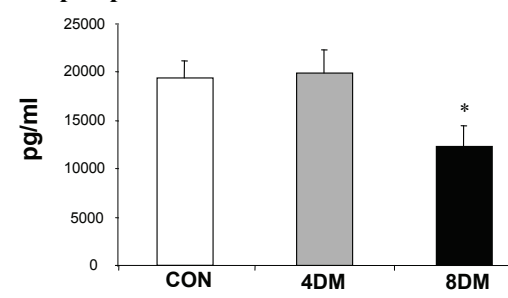

C: Plasma norepinephrine

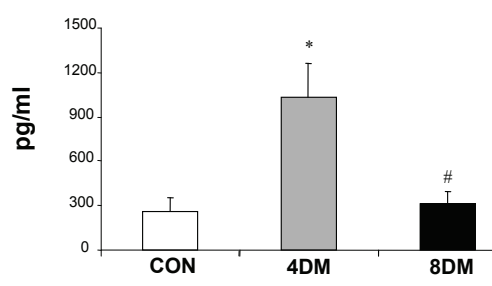

Figure 3. A. Severity of ventricular arrhythmias (arrhythmia score) and B plasma catecholamine levels after epinephrine injections in 4- and 8-wk diabetic animals. Diabetes was induced with a single intravenous injection of STZ $(65 \mathrm{mg} / \mathrm{kg})$. The values are mean \pm SEM of 5-8 experiments. CON, control; 4DM, 4-wk diabetes; 8DM, 8 -wk diabetes. ${ }^{*} \mathrm{P}<0.05$ vs. C; $\# \mathrm{P}<0.05$ vs. 4DM. 
prolongation of the QT and PR intervals were seen only in the 8-wk diabetic animals. Similar experimental and clinical observations have also been reported by others (21-24). While a dose-independent increase in the number of PVBs was seen in the 4-wk diabetic animals, the 8-wk diabetic rats were more resistant to Epi-induced PVBs as compared to control animals. In addition, the number of catecholamine-induced arrhythmias was higher in the 4-wk diabetic rats as compared to the 8-wk diabetic rats. In fact, the 8-wk diabetic rats were resistant to Epi-induced arrhythmias, indicating that ventricular arrhythmias induced by catecholamines are dependent on the stage of diabetes, in other words more ventricular arrhythmias were seen at early phase of diabetes. While the arrhythmia score and plasma Epi levels in the 4-wk diabetic animals were comparable to those of control animals, low plasma Epi levels in the 8-wk diabetic rats were associated with a lower severity of ventricular arrhythmias. In contrast, NE levels were increased in the 4-wk diabetic animals, but unchanged in the 8-wk diabetic rats.

Heart dysfunction in chronic diabetes has been observed to be associated with $\mathrm{Ca}^{2+}$ - handling abnormalities in cardiomyocytes as defects in the sarcoplasmic reticular (SR) and sarcolemmal (SL) calcium transport processes have been detected in the diabetic heart (25). Indeed, defects in SL Na $/ \mathrm{K}^{+}$-ATPase, $\mathrm{Na}^{+} / \mathrm{Ca}^{2+}$ exchanger, $\mathrm{Na}^{+} / \mathrm{H}^{+}$ exchange, $\mathrm{Ca}^{2+}$-channels and $\mathrm{Ca}^{2+}$-pump activities lead to increased concentration of cytosolic $\mathrm{Ca}^{2+}(26)$. The mechanism by which hyperglycaemia produces ventricular instability may be related to the increased sympathetic activity, increased cytosolic calcium content in cardiomyocytes, or both (27). Thus, it is reasonable to suggest that there is an increase in the risk of ventricular arrhythmias in early stage diabetes, which may be related to increased NE levels. On the other hand, a reduced susceptibility to ventricular arrhythmias in the 8-wk diabetic animals may be related to reduced catecholamine levels. In this regard, reduced plasma NE levels have been reported in long term human diabetes (28-31). A higher resistance against ischemia/reperfusion induced arrhythmias has also been reported (3235 ) and several mechanisms have been proposed. Recently, diabetic hyperglycemia has been demonstrated to activate $\mathrm{Ca}^{2+} /$ calmodulin-dependent protein kinase II (CaM KII), which results in increased spontaneous $\mathrm{SR} \mathrm{Ca}^{2+}$-release events that can contribute to cardiac arrhythmias (36). Furthermore, genetic ablation of CaM KII $\delta$ prevents high glucose induced arrhythmias (36). Accordingly the attenuation of arrhythmias in late stage of diabetes may be related to a reduction in CaM KII activity. However, some of our earlier observations $(18,37)$ have reported that although SR CaM KII activity is increased in the diabetic (6-wks post STZ-induced diabetes) heart, it is decreased in $10 \mathrm{wks}$ sucrose-fed rats (38). Therefore, it appears that changes in $\mathrm{CaM} \mathrm{KII}$ activity are biphasic in nature and dependent on the stage or severity of diabetes. Biphasic changes in $\mathrm{CaM}$ KII are also seen during the development of heart failure $(39,40)$. Consequently, some caution must be exercised in the implication of CaM KII in arrhythmias and cardiac dysfunction; thus, examination of the time course of changes in CaM KII activity as well as the development of experimentally induced arrhythmias is required before any meaningful conclusions can be made.

It is well known that excessive amounts of catecholamines play a major role in the induction of cardiac rhythm disorders (41). These effects are mediated through the activation of $\beta$-adrenoceptors-cAMP-PKA system. Furthermore, in view of the occurrence of oxidative stress in diabetes $(26,27$, 42 ), under conditions of increased catecholamines levels, there is an increase in the formation of catecholamine oxidation products, aminochromes, which have also been linked to arrhythmogenesis $(2,3)$. Since the plasma levels of both Epi and NE were reduced in the 8-wk diabetic animals, there could also be a reduced production of aminochromes and therefore a reduced susceptibility to catecholamine-induced arrhythmias. The reduced susceptibility of catecholamineinduced arrhythmias could also be, in part, related to the reported decrease in $\beta_{1}$ - and $\beta_{2}$ - adrenoceptors in diabetic hearts $(43,44)$. The $\alpha_{1}$ - adrenoceptor is known to modulate intracellular $\mathrm{Ca}^{2+}$ - concentration through the activation of phospholipase C-mediated generation of inositol trisphosphate and diacylglycerol $(20,45)$. The myocardial $\alpha_{1}$ - adrenoceptor signaling system has been reported to be impaired in STZ-induced diabetic rats $(46,47)$. Thus, it is possible that the resistance to arrhythmias in longer stage diabetes may be related to a reduced capacity for $\alpha 1$ - adrenoceptor mediated increases in intracellular $\mathrm{Ca}^{2+}$. It is pointed out that there is a selective reduction in myocardial $\mathrm{Na}^{+} / \mathrm{K}^{+}-\mathrm{AT}$ Pase, which reduces the capacity of the heart for maintaining $\mathrm{K}^{+}$- and $\mathrm{Ca}^{2+}$ - homeostasis in STZ-induced diabetes (48), and increasing the risk of arrhythmias. It is thus conceivable that stage-dependent changes in $\mathrm{Na}^{+} / \mathrm{K}^{+}$-ATPase may exist in diabetes and impacting on the susceptibility or attenuation to catecholamine-induced arrhythmias; a possibility that warrants further investigation.

\section{CONCLUSIONS}

Although cardiac function in the 4-wk diabetic animals was impaired, it did not deteriorate further in the 8-wk diabetic animals. The 8 -wk diabetic rats were more resistant to ventricular arrhythmias as compared to the 4-wk diabetic rats. The increased susceptibility of the 4-wk diabetic animals to ventricular arrhythmias was associated with an increase in plasma Epi levels. The reported higher incidence of sudden cardiac death in diabetic individuals may be due to other diabetes-induced cardiovascular complications.

\section{ACKNOWLEDGEMENTS}

This study was supported by a grant from the Slovak Scientific Grant Agency (VEGA) 1/0638/12 (AA). D.R-L. was a Visiting Scientist from Cardiovascular Research Di- 
vision, V.I. Lenin University Hospital, Holguin, Cuba. Infrastructural support for this project was provided by the St. Boniface Hospital Research Foundation.

\section{CONFLICTS OF INTEREST}

The authors declare no conflict of interest.

\section{REFERENCES}

1. Dhalla NS, Adameova A, Kaur M. Role of catecholamine oxidation in sudden cardiac death. Fund Clin Pharmacol 2010; 24: 539-46.

2. Sethi R, Rehsia NS, Jindal K, et al. Antiarrhythmic effects of some antioxidant vitamins in rats injected with epinephrine. Cardiovasc Toxicol 2009 9: 177-84.

3. Sethi R, Adameova A, Dhalla KS, et al. Modification of epinephrine-induced arrhythmias by N-acetyl-Lcysteine and vitamin E. J Cardiovasc Pharmacol Ther 2009; 14:134-42.

4. Adameova A, Abdellatif Y, Dhalla NS. Role of the excessive amounts of circulating catecholamines and glucocorticoids in stress-induced heart disease. Can J Physiol Pharmacol 2009; 8: 493-514.

5. Goyal BR, Mesariya P, Goyal RK, Mehta AA. Effect of telmisartan on cardiovascular complications associated with streptozotocin diabetic rats. Mol Cell Biochem 2008: 314: 123-31.

6. Malone MA, Schocken DD, Hanna SK, Liang X, Malone JI. Diabetes-induced bradycardia is an intrinsic metabolic defect reversed by carnitine. Metabolism 2007; 56: 1118-23.

7. Nobe S, Aomine M, Arita M, Ito S, Takaki R. Chronic diabetes mellitus prolongs action potential duration of rat ventricular muscles: circumstantial evidence for impaired $\mathrm{Ca}^{2+}$ channel. Cardiovasc Res 1990; 24: 381-9.

8. Casis O, Gallego M, Iriarte M, Sanchez-Chapula A. Effects of diabetic cardiomyopathy on regional electrophysiologic characteristics of rat ventricle. Diabetologia 2000; 43: 101-9.

9. Shimoni Y, Chen K, Emmett T, Kargacin G. Aldosterone and the autocrine modulation of potassium currents and oxidative stress in the diabetic rat heart. Br J Pharmacol 2008; 154: 675-87.

10. Jourdon P, Feuvray D. Calcium and potassium currents in ventricular myocytes isolated from diabetic rats. J Physiol 1993; 470: 411-29.

11. Fein FS. Diabetic cardiomyopathy. Diabetes Care 1990; 13: 1169-79.

12. Regan TJ, Ahmed S, Haidar B, Moschos C, Weisse A. Diabetic cardiomyopathy: Experimental and clinical observations. New Engl J Med 1994; 91: 776-8.

13. Ganguly PK, Pierce GN, Dhalla KS, Dhalla NS. Defective sarcoplasmic reticular calcium transport in diabetic cardiomyopathy. Am J Physiol 1983; 244: E528-35.

14. Rees SA, Curtis MJ. Specific IK1 blockade: a new antiarrhythmic mechanism? Effect of RP58866 on ventricular arrhythmias in rat, rabbit, and primate. Circulation 1993; 87: 1979- 1789.

15. Barta J, Sanganalmath SK, Kumamoto H, Takeda N, Édes I, Dhalla NS. Antiplatelet agents sarpogrelate and cilostazol affect experimentally-induced ventricular arrhythmias and mortality. Cardiovasc Toxicol 2008; 8: 127-35.

16. Walker MJ, Curtis MJ, Hearse DJ, et al. The Lambeth Conventions: guidelines for the study of arrhythmias in ischaemia infarction and reperfusion. Cardiovasc Res 1988; 22: 447-55.

17. Sanganalmath SK, Babick AP, Barta J, Kumamoto H, Takeda N, Dhalla NS. Antiplatelet therapy attenuates subcellular remodelling in congestive heart failure. J Cell Mol Med 2008; 12: 1728-38.

18. Vasanji Z, Dhalla NS, Netticadan T. Increased inhibition of SERCA2 by phospholamban in the type I diabetic heart. Mol Cell Biochem 2004; 261: 245-9.

19. Machackova J, Liu X, Lukas A, Dhalla NS. Reninangiotensin blockade attenuates cardiac myofibrillar remodelling in chronic diabetes. Mol Cell Biochem 2004; 261: 271-8.

20. Tappia PS, Asemu G, Aroutiounova N, Dhalla NS. Defective sarcolemmal phospholipase $C$ signaling in diabetic cardiomyopathy. Mol Cell Biochem 2004; 261: 193-9.

21. Sauviat MP, Feuvray D. Electrophysiological analysis of the sensitivity to calcium in ventricular muscle from alloxan diabetic rats. Basic Res Cardiol 1986; 81: 489-96.

22. Howarth FC, Jacobson M, Shafiullah M, Adeghate E. Long-term effects of streptozotocin- induced diabetes on the electrocardiogram, physical activity and body temperature in rats. Physiology 2005; 90 : 827-35.

23. Rana BS, Band MM, Ogston S, Morris AD, Pringle SD, Struthers AD. Relation of QT interval dispersion to the number of different cardiac abnormalities in diabetes mellitus. Am J Cardiol 2002; 90: 483-7.

24. Takebayashi K, Sugita R, Tayama K, Aso Y, Takemura Y, Inukai T. The connection between QT dispersion and autonomic neuropathy in patients with type 2 diabetes. Exp Clin Endocrinol Diabetes 2003; 111: 351-7.

25. Dhalla NS, Liu X, Panagia V, Takeda N. Subcellular remodeling and heart dysfunction in chronic diabetes. Cardiovasc Res 1998; 40: 239-47.

26. Dhalla NS, Takeda N, Rodriquez-Leyva D, Elimban V. Mechanisms of subcellular remodeling in heart failure due to diabetes. Heart Fail Rev 2014; 19: 87-99.

27. Marfella R, Rossi F, Giugliano D. Hyperglycemia and QT interval: time for re-evaluation. Diabetes Nutr Metab 2011; 14: 63-5.

28. Christensen NJ. Plasma catecholamines in long-term diabetics with and without neuropathy and in hypophysectomized subjects. J Clin Invest 1972; 51: 779-87. 
29. Porojan M, Costin M, Poantă L, et al. Autonomic neuropathy and plasma catecholamine in patients with diabetes mellitus. Rom J Intern Med 2010; 48: 341-5.

30. Heyman E, Delamarche P, Berthon P, et al. Alteration in sympathoadrenergic activity at rest and during intense exercise despite normal aerobic fitness in late pubertal adolescent girls with type 1 diabetes. Diabetes Metab 2007; 33: 422-9.

31. Kondo K, Matsubara T, Nakamura J, Hotta N. Characteristic patterns of circadian variation in plasma catecholamine levels, blood pressure and heart rate variability in Type 2 diabetic patients. Diabet Med 2002; 19: 359-65.

32. Tosaki A, Engelman DT, Engelman RM, Das DK. The evolution of diabetic response to ischemia/reperfusion and preconditioning in isolated working rat hearts. Cardiovasc Res 1996; 31: 526-36.

33. Feuvray D, Lopaschuk GD. Controversies on the sensitivity of the diabetic heart to ischemic injury: the sensitivity of the diabetic heart to ischemic injury is decreased. Cardiovasc Res 1997; 34: 113-20.

34. Adameová A, Kuzelová M, Andelová E, et al. Hypercholesterolemia abrogates an increased resistance of diabetic rat hearts to ischemia-reperfusion injury. Mol Cell Biochem 2007; 295: 129-36.

35. Ravingerová T, Adameová A, Matejíková J, et al.. Subcellular mechanisms of adaptation in the diabetic myocardium: Relevance to ischemic preconditioning in the nondiseased heart. Exp Clin Cardiol 2010; 15: 68-76.

36. Erickson JR, Pereira L, Wang L, et al. Diabetic hyperglycemia activates CaMKII and arrhythmias by O-linked glycosylation. Nature 2013; 502: 372-6.

37. Netticadan T, Temsah RM, Kent A, Elimban V, Dhalla NS. Depressed levels of $\mathrm{Ca}^{2+}$-cycling proteins may underlie sarcoplasmic reticulum dysfunction in the diabetic heart. Diabetes 2001; 50: 2133-8.

38. Vasanji Z, Cantor EJ, Juric D, Moyen M, Netticadan T. Alterations in cardiac contractile performance and sarcoplasmic reticulum function in sucrose-fed rats is associated with insulin resistance. Am J Physiol Cell Physiol 2006; 291: C772-80.

39. Anderson ME, Brown JH, Bers DM. CaMKII in myocardial hypertrophy and heart failure. J Mol Cell Cardiol 2011; 51:468-73.

40. Netticadan T, Temsah RM, Kawabata K, Dhalla NS. Sarcoplasmic reticulum $\mathrm{Ca}^{2+} /$ Calmodulin-dependent protein kinase is altered in heart failure. Circ Res 2000; 86: 596-605

41. Bhagat BD, Rao PS, Dhalla NS. Role of catecholamines in the genesis of arrhythmias. Adv Myocardial 1980; 2: 117-32.

42. Xu YJ, Tappia PS, Neki NS, Dhalla NS. Prevention of diabetes-induced cardiovascular complications upon treatment with antioxidants. Heart Fail Rev 2014; 19:113-21.

43. Dinçer UD, Bidasee KR, Güner S, Tay A, Özçelikay T, Altan MV. The effect of diabetes on expression of $\beta 1-$, $\beta 2-$, and $\beta 3$-adrenoreceptors in rats hearts. Diabetes 2001; 50: 455-61.

44. Op den Buijs J, Miklos Z, Van Riel NAW, et al. $\beta$-adrenergic activation reveals impaired cardiac calcium handling at early stage of diabetes. Life Sci 2005; 76: 1083-98.

45. Woodcock EA, Arthur JF, Matkovich SJ. Inositiol 1,4,5trisphosphate and reperfusion arrhythmias. Clin Exp Pharmacol Physiol 2000; 27:734-7.

46. Tanaka Y, Kashiwagi A, Saeki Y, Shigeta Y. Abnormalities in cardiac $\alpha 1$-adrenoceptor and its signal transduction in streptozotocin-induced diabetic rats. Am J Physiol 1992; 263: E425-9.

47. Tanaka Y, Kashiwagi A, Saeki Y, et al. Effects of verapamil on the cardiac $\alpha 1$-adrenoceptor signaling system in diabetic rats. Eur J Pharmacol 1993; 244: 105-9.

48. Ziegelhöffer A, Bundgaard H, Ravingerová, et al. Diabetes - and semi-starvation-induced changes in metabolism and regulation of $\mathrm{Na}, \mathrm{K}$-ATPase in rat heart. Diabetes Nutr Metab 2003; 16: 222-31. 